\title{
Cystoisospora Species Insights From Development in vitro
}

\author{
David S. Lindsay* \\ Zoonotic Protozoal Diseases Laboratory, Department of Biomedical Sciences and Pathobiology, Center for One Health \\ Research, Virginia Maryland College of Veterinary Medicine, Virginia Tech, Blacksburg, VA, United States
}

Keywords: cell culture, Cystoisospora belli, Cystoisospora canis, Cystoisospora felis, Cystoisospora rivolta, Cystoisospora suis, endodyogeny, tissue cyst

\section{OPEN ACCESS}

Edited by:

Luís Pita Gondim,

Federal University of Bahia, Brazil

Reviewed by:

Milton McAllister,

University of Adelaide, Australia

*Correspondence:

David S. Lindsay

lindsayd@vt.edu

Specialty section:

This article was submitted to

Parasitology,

a section of the journal

Frontiers in Veterinary Science

Received: 19 September 2018 Accepted: 14 December 2018 Published: 09 January 2019

Citation:

Lindsay DS (2019) Cystoisospora Species Insights From Development

in vitro. Front. Vet. Sci. 5:335

doi: 10.3389/fvets.2018.00335
The Genus Cystoisospora was created in 1977 (1) to account for the recently described facultative two-host life cycles observed occurring in feline and canine Isospora species $(2,3)$. The justification for the creation of the Genus Cystoisospora and placement of mammalian Isospora species in it was based on morphological, biological, and genetic differences between Isospora species from nonmammalian hosts and mammalian hosts (4-6). The orally infectious tissue cyst stage present in the intermediate host contains a single asexual stage and is referred to as a monozoic tissue cyst (MZTC) because it contains a single organism within a parasitophorous vacuole surrounded by a tissue cyst wall (7-9). The stage is classified as a zoite because it has all the ultrastructural features found in sporozoites, tachyzoites, and bradyzoites of other Sarcocystidae. Most notably the zoite contains a crystalloid body observed in sporozoites of Cystoisospora species (10). Crystalloid bodies are spherical accumulations of granular cytoplasmic inclusions similar to beta-glycogen particles. They are in the same location of the sporozoite as are refractile bodies of Eimeria species sporozoites excysted from oocysts (11) and occasionally early generation merozoites of Eimeria species (12). Crystalloid bodies and refractile bodies are believed to serve as sites of energy storage to maintain the dormant sporozoites until they are ingested by a host and become metabolically active. The presence of crystalloid bodies in sporozoites in oocysts and zoites in MZTC of Cystoisospora is now recognized as a feature useful in their identification (6).

It is not known if zoites originate from oocysts that have excysted and represent sporozoites that migrate to extra-intestinal sites without developing or if they represent a post divisional stage, such as a tachyzoite, bradyzoite, or merozoite. This remains one of the most important questions concerning the biology of this group and has important implications in the management of C. belli infections in immune compromised patients. However, the tremendous number of MZTC each containing a single zoite observed in tissues of immune suppressed patients with $C$. belli infections indicates that zoites in MZTC represent an asexual stage that has been produced by multiplication either by endodyogeny or another form of merogony and has migrated to its location of encystation and became a MZTC (13).

Pioneering studies on the development of Cystoisospora species in cell cultures were conducted by Dr. Ron Fayer at the United States Department of Agriculture in Beltsville, Maryland, from 1972 to 1974 (14-16). These studies demonstrated that sporozoites excysted from oocysts of C. rivolta and C. felis collected from cats, and sporozoites of C. canis from dogs, entered cultured cells and divided repeatedly by endodyogeny. They provided a foundation for future studies of the medically important C. belli from humans and economically important C. suis in young swine.

Cystoisospora rivolta developed in feline kidney cells, embryonic bovine kidney cells, and MadinDarby canine kidney (MDCK) cells (14). Development was delayed by $24 \mathrm{~h}$ and was minimal in in MDCK cells. Cystoisospora felis developed in embryonic intestine, esophageal epithelium, amnion, lung, and Hela cells from humans, kidney cells from chickens, embryonic tracheal cells from bovines, and MDCK cells from dogs but cells from cats were not examined (16). Development by $C$. felis was similar in all these cell types. 
Development of sporozoites of $C$. canis was examined in MDCK cells and primary cells from embryonic canine kidneys, and embryonic canine intestine as well as embryonic bovine trachea and kidney (15). Development by endodyogeny occurred in all host cell types 3-4 days after inoculation. A study of development of $C$. canis sporozoites using bovine turbinate and African green monkey kidney (CV-1) cells provided remarkedly different findings of no asexual multiplication but rather MZTC formation in both host cell types (17). Examination of these stages using transmission electron microscopy confirmed they were MZTC and that they were similar to C. belli MZTC in the tissues of humans $(13,18), C$. canis in mice (9), C. ohioensis in mice (8) and C. felis in mice (19). The organisms in these MZTC all contain crystalloid bodies when viewed using transmission electron microscopy. An in-depth study was conducted on the biology of MZTC of C. canis using two canine, four human, one monkey, and one bovine cell lines (20). No asexual multiplication occurred in any cell line however MZTC were produced in all cell lines. It is important to note that MDCK cells were used by both Fayer and Mahrt in their study (15) and Houk and Lindsay in their study (20) with dramatically different results. When host cells containing MZTC were exposed to excystation solution ( $0.75 \%$ sodium taurocholic acid and $0.25 \%$ trypsin solution) the sporozoites became motile and exited the MZTC and were able to infect new host cells and produce MZTC again. The same events occurred, except the tissue cyst wall was dissolved by the acid-pepsin solution, when MZTC were exposed to acidpepsin solution suggesting survival through the stomach and oral infectiousness of this stage (20). Additional research is needed to account for these different findings between these three $C$. canis isolates by different research groups. It suggests that two different genetic types of $C$. canis exist and that one divides by endodyogeny in culture and the other produces MZTC. How this would translate to in vivo development and pathogenicity in dogs is also an interesting area needing research.

The initial studies on the development of C. suis in five types of mammalian host cells in culture indicated that development was by endodyogeny (21) and stages were structurally similar to Type I meronts observed in neonatal pigs (22). Similar findings were observed in primary porcine kidney cells and primary embryonic bovine kidney cells (23). However, stages suggestive of multinucleate Type II meronts were seen in primary porcine kidney cells but no merozoites were produced (23). The ultrastructural aspects of C. suis development of Type I meronts by endodyogeny in these cell cultures (24) was examined and the findings were not different from those reported to occur in the small intestinal epithelial cells of infected pigs (25). Notably crystalloid bodies were seen in Type I merozoites in vitro (24). Complete development of C. suis was observed in a swine testicular cell line (26). Development was delayed

\section{REFERENCES}

1. Frenkel JK. Besnoitia wallacei of cats and rodents: with a reclassification of other cyst-forming isosporid coccidia. J Parasitol. (1977) 63:611-28. doi: $10.2307 / 3279560$
2-4 days and most stages were Type I meronts and merozoites. The ultrastructure of microgamonts, microgametes, and oocysts were described (26). Oocysts did not sporulate in culture. Studies conducted in 2013 using a porcine intestinal epithelial cell line reported similar results (27). The study demonstrated that high densities of gamonts occurred at 12 days after infection and found that an optimum infective dose was one sporozoite per 100 host cells (27).

No evidence of MZTC formation has been reported in cell cultures. Similarly, studies in pigs and potential paratenic hosts have been negative $(28,29)$. This is puzzling because the biology of $C$. suis conforms to all other reported features of the genus.

Four studies have examined development of sporozoites obtained from oocysts of $C$. belli in human and other mammalian cell cultures (30-33). The studies have demonstrated that development occurs in several cell types from humans including those derived from human ileocecal adenocarcinoma (HCT-8), epithelial carcinoma of the lung, and macrophages. Other mammalian cells examined have consisted of mouse macrophages, Madin-Darby bovine kidney, Rhesus monkey kidney (RMK) and African green monkey kidney (VERO) cells. Endodyogeny was described in HCT-8 cells and RMK cells using transmission electron microscopy (32). The authors found no crystalloid bodies in merozoites of $C$. belli as are present in $C$. suis (24) while undergoing endodyogeny in vitro but otherwise the structural findings were similar to those reported for C. suis. Stages of $C$. belli obtained from macrophage cell cultures were infectious for RMK cells upon subinoculation and development by endodyogeny occurred (31) but MZTC were not reported.

I have attempted to point out the similarities and important differences in the development of Cystoisospora species from mammals and to provide insight into future research directions. Development will occur in many host cell types but studies with C. suis illustrate that selection of the proper host cell type can lead to complete development thus increasing the utility of an in vitro system. Studies with $C$. canis suggest that genetic differences in Cystoisospora species exist that are reflected by the phenotype of development expressed in vitro. I look forward to seeing what advances in our knowledge of this group are revealed in the future.

\section{AUTHOR CONTRIBUTIONS}

The author confirms being the sole contributor of this work and has approved it for publication.

\section{ACKNOWLEDGMENTS}

I wish to thank Virginia Tech for funding to defray costs of this contribution.

2. Dubey JP, Frenkel JK. Extra-intestinal stages of Isospora felis and I. rivolta (Protozoa: Eimeriidae) in cats. J Protozool. (1972) 19:89-92. doi: 10.1111/j.1550-7408.1972.tb03419.x

3. Frenkel JK, Dubey JP. Rodents as vectors for feline coccidia Isospora felis and Isospora rivolta. J Infect Dis. (1972) 125:69-72. doi: 10.1093/infdis/125.1.69 
4. Carreno RA, Schnitzler BE, Jeffries AC, Tenter AM, Johnson AM, Barta JR. Phylogenetic analysis of coccidia based on 18S rDNA sequence comparison indicates that Isospora is most closely related to Toxoplasma and Neospora. J Euk Microbiol. (1998) 45:184-8. doi: 10.1111/j.1550-7408.1998. tb04523.x

5. Barta JR, Schrenzel MD, Carreno R, Rideout BA. The genus Atoxoplasma (Garnham 1950) as a junior objective synonym of the genus Isospora (Schneider 1881) species infecting birds and resurrection of Cystoisospora (Frenkel 1977) as the correct genus for Isospora species infecting mammals. J Parasitol. (2005) 91:726-7. doi: 10.1645/GE-3341.1

6. Lindsay DS, Houk AE, Mitchell SM, Dubey JP. Developmental biology of Cystoisospora (Apicomplexa: Sarcocystidae) monozoic tissue cysts. J Parasitol. (2014) 100:392-9. doi: 10.1645/13-494.1

7. Dubey JP. Life cycle of Isospora rivolta (Grassi 1879) in cats and mice. J Protozool. (1979) 26:433-43. doi: 10.1111/j.1550-7408.1979. tb04650.x

8. Dubey JP, Mehlhorn H. Extraintestinal stages of Isospora ohioensis from dogs in mice. J Parasitol. (1978) 64:689-95. doi: 10.2307/ 3279961

9. Markus MB. The hypnozoite of Isospora canis. S Afr J Sci. (1983) 79:117.

10. Roberts WL, Mahrt JL, Hammond DM. The fine structure of sporozoites of Isospora canis. Z Parasitenkund. (1972) 40:183-94.

11. Roberts WL, Hammond DM. Ultrastructural and cytologic studies of the sporozoite of four Eimeria species. J Protozool. (1970) 17:76-86. doi: 10.1111/j.1550-7408.1970.tb05161.x

12. Hammond DM, Speer CA, Roberts WL. Occurrence of refractile bodies in merozoites of Eimeria species. J Parasitol. (1970) 58:189-91. doi: $10.2307 / 3277482$

13. Lindsay DS, Dubey JP, Toivio-Kinnuncan MA, Michiels FJ, Blagburn BL. Examination of extraintestinal tissue cysts of Isospora belli. J Parasitol. (1997) 83:620-5. doi: 10.2307/3284235

14. Fayer R. Cultivation of feline Isospora rivolta in mammalian cells. J Parasitol. (1972) 58:1207-8. doi: 10.2307/3278169

15. Fayer R, Mahrt JL. Development of Isospora canis (Protozoa; Sporozoa) in cell culture. Z Parasitenkünd. (1972) 38:313-8. doi: 10.1007/BF00329278

16. Fayer R, Thompson DE. Isospora felis: development in cultured cells with some cytological observations. J Parasitol. (1974) 60:160-8. doi: $10.2307 / 3278693$

17. Mitchell SM, Zajac AM, Lindsay DS. Development and ultrastructure of Cystoisospora canis Nemeséri, 1959 (syn. Isospora canis) monozoic cysts in two noncanine cell lines J Parasitol. (2009) 95:793-8. doi: 10.1645/GE-1951.1

18. Restrepo C, Macher AM, Radany EH. Disseminated extraintestinal isosporiasis in a patient with acquired immune deficiency syndrome. Am J Clin Pathol. (1987) 87:536-42. doi: 10.1093/ajcp/87.4.536

19. Mehlhorn H, Markus MB. Electron microscopy of stages of Isospora felis of the cat in the mesenteric lymph nodes of the mouse. Z Parasitenkund. (1976) 51:25-9. doi: 10.1007/BF00380524

20. Houk AE, Lindsay DS. Cystoisospora canis (Apicomplexa: Sarcocystidae): development of monozoic tissue cysts in human cells, demonstration of egress of zoites from tissue cysts, and demonstration of repeat monozoic tissue cyst formation by zoites. Vet Parasitol. (2013) 197:455-61. doi: 10.1016/j.vetpar.2013.07.022
21. Fayer R, Gamble HR, Ernst JV. Isospora suis: development in cultured cells with some cytological observations. Proc Helminthol Soc Wash. (1984) 51:154-9.

22. Lindsay DS, Stuart BP, Wheat BE, Ernst JV. Endogenous development of the swine coccidium, Isospora suis Biester 1934. J Parasitol. (1980) 66:771-9. doi: $10.2307 / 3280667$

23. Lindsay DS, Blagburn BL. Development of Isospora suis from pigs in primary porcine and bovine cell cultures. Vet Parasitol. (1987) 24:301-4. doi: 10.1016/0304-4017(87)90052-5

24. Lindsay DS, Blagburn BL, Toivio-Kinnucan MA. Ultrastructure of developing Isospora suis in cultured cells. Am J Vet Res. (1991) 52:471-3.

25. Matuschka FR. Ultrastructural evidence of endodyogeny in Isospora suis from pigs. Z Parasitenkund. (1982) 67:27-30. doi: 10.1007/BF00929510

26. Lindsay DS, Quick DP, Steger MA, Toivio-Kinnucan MA, Blagburn BL. Complete development of the porcine coccidium Isospora suis Biester, 1934 in cell cultures. J Parasitol. (1998) 84:635-7. doi: 10.2307/3284741

27. Worliczek HL, Ruttkowski B, Schwarz L, Witter K, Tschulenk W, Joachim A. Isospora suis in an epithelial cell culture system - An in vitro model for sexual development in coccidia. PLoS ONE (2013) 8:e69797. doi: 10.1371/journal.pone.006979

28. Stuart BP, Bedell DM, Lindsay DS. Coccidiosis in swine: a search for extraintestinal stages of Isospora suis. Vet Rec. (1982) 110:82-3. doi: $10.1136 /$ vr.110.4.82

29. Pinckney RD, Lindsay DS, Toivio-Kinnucan MA, Blagburn BL. Ultrastructure of Isospora suis during excystation and attempts to demonstrate extraintestinal stages in mice. Vet Parasitol. (1993) 47:225-33. doi: 10.1016/0304-4017(93)90024-H

30. Oliveira-Silva MB, Lages-Silva E, Resende DV, Prata A, Ramirez LE, Frenkel JK. Cystoisospora belli: in vitro multiplication in mammalian cells. Exp Parasitol. (2006) 114:189-92. doi: 10.1016/j.exppara.2006.03.004

31. Resende DV, Lages-Silva E, Assis DC, Prata A, OliveiraSilva MB. Experimental infection of murine and human macrophages with Cystoisospora belli. Acta Trop. (2009) 111:177-80. doi: 10.1016/j.actatropica.2009.04.010

32. Resende DV, Assis DC, Ribeiro MF, Cabrine-Santos M, Frenkel JK, Correia D, et al. Ultrastructural aspects of Cystoisospora belli (syn. Isospora belli) in continuous cell lines Microsc Res Tech. (2014) 77:472-8. doi: $10.1002 /$ jemt.22372.

33. Siripanth C, Punpoowong B, Amarapal P, Thima N. Development of Isospora belli in Hct-8, Hep-2, human fibroblast, BEK and Vero culture cells. SE Asian J Trop Med Pub Health (2004) 35:796-800.

Conflict of Interest Statement: The author declares that the research was conducted in the absence of any commercial or financial relationships that could be construed as a potential conflict of interest.

Copyright (c) 2019 Lindsay. This is an open-access article distributed under the terms of the Creative Commons Attribution License (CC BY). The use, distribution or reproduction in other forums is permitted, provided the original author(s) and the copyright owner(s) are credited and that the original publication in this journal is cited, in accordance with accepted academic practice. No use, distribution or reproduction is permitted which does not comply with these terms. 